\title{
Benchlearning - an action research program for transforming leadership and school practices
}

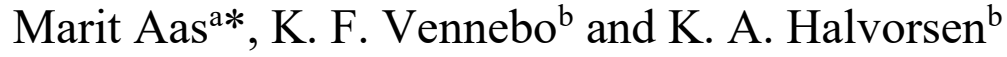 \\ ${ }^{a}$ Department of Teacher Education and School Research, University of Oslo, Oslo, Norway; \\ ${ }^{b}$ Department of Teacher Education and School Research, University of Oslo, Oslo, Norway; ${ }^{c}$ \\ Department of Teacher Education and School Research, University of Oslo, Oslo, Norway
}

Marit Aas, Professor, Department of Teacher Education and School Research University of

Oslo, Norway, marit.aas@ils.uio.no; *corresponding author

Marit Aas is Professor at University of Oslo. Her research consists of School Leadership, School Development, Coaching. She has a background as a practitioner in school (teacher, principal, etc).

Kirsten Foshaug Vennebo is Associate Professor. Her research consists of School leadership, Innovation and ICT and school leadership development. She has a background as a practitioner in school (teacher, principal, etc) and as a leader in the business sector.

Kjell Atle Halvorsen is Associate Professor at the Norwegian University of Science and Technology. His research consists of school and classroom leadership, leadership education, and ICT in schools. He has a backround as teacher and school leader, project manager and head of school leadership programs.

Acknowledgement:

Lillemor Rehnberg, Uppsala University, Sweden

Ulf Buskquist, Karlstad University, Sweden 


\title{
Benchlearning - an action research program for transforming leadership and school practices
}

\author{
In this paper, we investigate how a benchlearning program for principals in \\ Norway and Sweden supports changes in Norwegian principals' leadership \\ practices. The program design builds on principles for practical action research. \\ The aim of the program is to inspire changes in the principals' leadership \\ practices that encourage innovative school practices. The program includes \\ learning modes such as theoretical inputs, sharing experiences, school visits, \\ training, and trialling of new leadership practices. Drawing on data from \\ participants' reflections on their learning and changes in their leadership \\ practices, we identify transformations that have been realized and the ways in \\ which the benchlearning program has supported the transformations. The \\ findings indicate that the program can be seen as a systematic and disciplined \\ process, a "meta-practice", that supports changes in the principals' leadership \\ practices, their understandings and the conditions of their practice. More \\ specifically, the findings show that the theoretical inputs and practical learning \\ modes stimulated transformations of the principals' thinking about leadership \\ practices, what they do in practice and how they relate to others. In particular, the \\ study suggests that the principals' active participation in trialling new leadership \\ practices in their own schools stimulated transformations.
}

Keywords: Benchlearning, action research, leadership practices, transformations

\section{Introduction}

Leadership is key to managing school development work and sustaining change to improve educational outcomes (Aas, 2009; Fullan, 2015; Hargreaves \& Shirley, 2012; Vennebo, 2015). This is an insight supported by research and reflected in the educational policies of a number of countries (OECD, 2008, 2013b; Research, 2017). Thus the expectations of and requirements for principals are high and likely to increase. Consequently, programs for school leadership development offered by universities and colleges have been subject to intense, critical scrutiny. 
In its report on improving school leadership, the OECD (2008) concluded that school leaders are prepared for a role that was designed for the industrial age, a role that has not changed enough to deal with the complex challenges of the twenty-first century. These complex challenges include managing change, building organizational capacity, implementing technological advances, increasing effectiveness, and striving to improve the learning outcomes of students (Fluckiger, Lovett, \& Dempster, 2014).

Consequently, leaders may be required to assume the roles of educational visionaries, change agents, instructional leaders, budget analysts, facility managers, and community organizers in their schools (Robinson, 2010). The need to develop a more innovative learning environment is also emphasized in the OECD report "Leadership for 21st Century Learning" (OECD, 2013b). Although greater attention is paid to redesigning school leadership programs than in the past (Huber, 2011), there is a growing concern that school leadership programs lack a robust research base and continue to be inadequate (Crow \& Whiteman, 2016; Darling-Hammond, LaPointe, Meyerson, \& Orr, 2007; Hallinger, 2011; Lovett, Dempster, \& Flückiger, 2015). In their analyses of eight high-performing international school systems, McKinsey and Company (2010) found that improvement of leadership capacity is an area where more has to be done.

According to Huber (2010), there is a need to create and use innovative approaches for making programs effective in the sense of improving school leaders' learning outcomes. He argues that the modes of learning - feedback, collegial exchange, courses, and self-studies -drawn into a reciprocal relationship with practice should be included in effective programs. His arguments are supported by DarlingHammond et al. (2007), who recognize the importance of problem-based learning scenarios that integrate theory and practice, and emphasize the management of school operations and leadership for school improvement. Such programs should be 
accompanied by field-based projects, such as action research, analyses, and discussion of case studies, as well as a portfolio of evidence about practice.

This paper reports from a larger study of the Benchlearning program for principals in Norway and Sweden, which aims to inspire changes in the principals' leadership practices to encourage the development of innovative school environments (Aas \& Blom, 2017) This paper sets out to investigate changes in leadership and school practices that have evolved through principals' participation in the program, and the ways in which the principals perceive that the program has supported the changes.

In the first section, we lay the foundation for our research interest by examining international literature about modes of learning for school leadership development. We then briefly describe the Benchlearning program. The next section presents the methodology, which includes a variety of data. Finally, we present the results, discuss the findings and conclude.

\section{Modes of learning for school leadership development}

Modes of learning for school leadership development involve different ways in which learning occurs. Over the last decades, new approaches to modes of learning have been developed and utilized in school leadership programs organised and offered by universities and colleges (Huber, 2011). In addition to the cognitive (theoretical) approaches that have dominated the field, which mainly provide information through lecturing and self-study, alternative learning modes are now utilized because they are considered more effective. Students and faculty members are often required to interact with each other through collaboration, discussions, experiments, feedback, and reflection. New approaches to leadership development may involve project-work,action research, coaching and/or mentoring (Crow \& Whiteman, 2016; Huber, 2010; Jensen, 2017). 
However, as Huber (2011) illustrates through his model of approaches to learning for school leadership development, no matter what mode of learning is engaged, each must be drawn into a reciprocal relationship with practice to be effective. This demonstrates how school leaders' experience and practice are crucial in the learning process and corresponds with Heck and Hallinger's (2014) argument that the purpose of leadership development is to give leaders the theoretical and practical knowledge that can lead to changes in their daily practice. The recognition of the link between practice and theory as a means of changing leaders' practice is also demonstrated in a study of school leaders participating in the Norwegian National Leadership Program (Aas, 2016b). According to Hunzicker (2011), professional learning is considered relevant and authentic for adult learners when it is job-embedded, instructionally focused, collaborative, supportive, and ongoing. This link with the real world of praxis is also emphasized by Kolb (1984), Cochran-Smith and Lytle (1999), and Robertson (2016). Hunzicker (2011) suggests that adults as learners are motivated by solving problems that relate directly to their lives and that create enduring solutions. Such connections to practice help the transfer of knowledge.

Robertson (2013) argues that it makes a considerable difference whether school leaders think that they are part of the change process or they think that the change process is about others. Learning leadership is not just about gaining more knowledge. It must provide opportunities for leaders to thinking more about knowledge as well. Metacognitive skills can help the individual leader to understand what the new knowledge means for school leadership practice, and for the individual's identity development as a school leader. Seeing leadership as a practice and learning from day to day practice is an important skill for leaders. Leadership as practice offers in itself transformative learning opportunities, and leadership as learning enables effective 
learning from professional practice (Aas, 2016a; Robertson, 2013). However, many leaders are not concerned with their own learning, and they do not necessarily have a metacognitive insight into their own thought processes required to take a step back and take control of their own learning (Lucas \& Claxton, 2010). An awareness of your competencies and incompetencies and an ability to identify how and why you think in specific ways is important in leaders' learning processes. In a synthesis of metacognition, Dawson (2008) argues that adults with well-developed metacognitive skills are better problem solvers, better at making decisions, more critical thinkers, more motivated to learn, better at regulating their feelings, and better at handling complexity and conflicts. This argument emphasizes the importance of learning and development of reflexive skills (Dempster, Lovett, \& Fluckiger, 2011).

According to Argyris and Schön (1978), reflection involves both single-loop and double-loop learning. Single-loop learning is defined as small adjustments of rules and routines, while dual-loop learning is about new ways of thinking and acting. Hargrove (2008) argues that reflection also includes triple-loop learning, which involves thinking about the school context and dramatic shift in terms of perspective and behaviour. The importance of integrating learning modes in a program for school leadership development that supports the development of metacognitive skills is supported by Hallinger and Heck, who state:

'Leaders who possess a single set of tools will find themselves bouncing around from success to failure without understanding why. The capacity to read your context correctly and adapt your leadership to the needs largely determines your success.' (2010, p. 137)

By building learning around the leaders' experiences and practices, theory and practice can be linked together through collaborative reflexive activities (Aas, 2016a; Dempster et al., 2011). In other words, school leaders being active and involved in 
development processes in their own school is crucial to their own and their schools' learning and for remaking practices. This corresponds to practical action research (Kemmis, 2009), building on collaborative and self-reflective principles by which practitioners remake their practice for themselves. Action research may be called a practice-changing-practice and as such a mode of learning for school leadership development. It may be thought of as an action-oriented meta-learning practice. It can be a more or less systematic, more or less disciplined critical and self-critical process that animates and urges changes in practice, understandings and the conditions of practices through individual and collective self-reflective transformation (Kemmis, 2009). According to Kemmis (2009, p. 463) transforming practices means what we do; transforming understandings means transforming what we think and say, and transforming the conditions of practice means transforming the ways we relate to others and to things and circumstances around us. Kemmis (2009) speaks of these three things as 'sayings', 'doings', and 'relatings' and maintain that each can be transformed, but each is always transformed in relation to the others.

In the next section, we will describe the context of and the Benchlearning program which builds on principles for practical action research.

\section{The Benchlearning Program}

The educational policies of Sweden and Norway reflect many similarities regarding educational ideologies. Both countries have a comprehensive educational system, a strong state, loyalty to and acceptance of state governing, and municipalities as relatively independent political institutions (Møller, 2009; Nihlfors \& Johansson, 2013). Compared to other countries, Norway and Sweden have a large public sector, and local 
municipalities play a strong role in school governance. ${ }^{1}$ The municipality finances the schools, employs principals and teachers, and plays a key role in providing in-service training for teachers and principals. The two countries' educational systems are predominantly public, which means that state authorities run most schools and universities. Education is free at all levels. There is no streaming according to ability, gender, or other factors, and most students are enrolled in regular classes. Since the end of the 1980s, the education systems in both countries have undergone major reforms, influenced largely by new managerial ideas. Despite the many similarities between Norway and Sweden, there are also some differences. They have developed different national assessment systems (Skott \& Kofod, 2013), and while Sweden during the last 15 years has opened up for independent schools, Norway has a rather limited private sector (Møller \& Skedsmo, 2013).

The Benchlearning program is a bilateral collaborative learning program for principals in Norway and Sweden. The program, which has been offered to about 210 principals in the two countries, is a collaborative project between the Swedish and the Norwegian National Agencies of Education. Four process leaders, two from Sweden and two from Norway, have been running the program. The process leaders are all running national principal programs in the two countries. The aim of the program is to empower the participants to develop leadership practices and school environments that are more innovative, inspired by the two OECD reports "Innovative Learning Environments" (OECD, 2013a) and "Leadership for 21st Century Learning" (OECD, 2013b). For the third and fourth groups leadership and ICT was given particular

\footnotetext{
${ }^{1}$ The 429 municipalities in Norway and 290 in Sweden are responsible for compulsory education at the primary and lower-secondary school levels. The municipalities vary in size as well as in levels of welfare.
} 
attention. The design of the program includes theoretical inputs, sharing experiences, school visits, and training in new leadership practices (Aas \& Blom, 2017).

The program contains two modules, each consisting of two and a half day meeting. For module one participants meet in Sweden in October, for module two in Norway in March/April. The participants are organized in learning groups of principals from both countries and within the same type of school. One of the four process leaders is assigned as mentor to each group, the members of which work together throughout the whole program. Participants prepare for module one by reading texts about innovative learning environments and learning leadership. They also reflect on the learning environment at their own school, on what it means for the school and for themselves as principals. Participants in group four were required to produce a short introductory video, which were posted on a closed YouTube channel.

Module one provides theoretical input on learning leadership and innovative learning environments, based to a large extent on the OECD reports. This theoretical framework creates a screen to help participants describe what they see during the school visits and to analyze and reflect on their observations. Participants are also trained to observe without judgment and be aware of how previous experiences have influenced them. At the end of module one participants identify innovative measures that they will initiate in their own schools, how the school environment will be affected and involved, and what their next step will be. This action plan is shared with fellow participants on Google Drive. Between modules participants post short reports on their experiences from leading innovative school leadership processes in their schools. These reports are also posted on Google Drive, which is used as a collaborative learning platform throughout the program. The organization of material on the platform is transparent across groups in order to increase participation and to enhance sharing and learning 
from each other's reflections and experiences. Based on feedback from group one, participants in groups two and three were organized in pairs of learning partners with a responsibility for commenting on each other's reports in order to enhance learning interactions between participants. For group four, two internet meetings for the learning groups and their mentors were introduced to support the school based activities between modules.

The venue for the second module is in Norway. Participants exchange experiences of leading innovative school development between modules, as well as their reflections on the process and the literature. Like in module one, considerable time is spent preparing for school visits, with subsequent analyses of and reflections on their observations. This module also includes theoretical input, focusing on innovative learning environments, learning leadership, and school development. For cohorts three and four particular attention was given to affordances and challenges provided by digital technologies. At the end of module two participants reflect on the Benchlearning process, their own learning, and further develop of their schools individually and in groups.

\section{Methods}

In this article, we draw on data from the three of the four groups (150 participants) who completed the program, in June 2015, June 2016, and June 2017, respectively. The data are based on individual reflection documents from students on their learning and new leadership practices four months, sixteen months and twenty-eight months after the end of the program.

In addition, the Norwegian Directorate of Education conducted an online survey of participants about their experiences of the program, and there are a number of 
documents produced in the learning groups on Google Drive throughout the program. The latter include individual reflection documents made before the program started, in the period between modules, and at the end. All documents related to the participants' own learning, the learning groups' preparation for school visits, their analyses, and the final school reports. Together, the documents on Google Drive provide a longitudinal perspective on the participants' learning. When it comes to the survey and process documents on Google Drive, the data are not subject to systematic analysis in this article. However, they form a contextual backdrop for the analyses. In sum, the survey and process documents provide a picture of great participant satisfaction with the program. Furthermore, they shed light on the challenges encountered by school leaders with regard to understanding and managing the complexities they face in their daily practice.

To qualify for participation in a follow-up meeting in November 2017 school leaders who completed Benchlearning in 2015, 2016 and 2017 were required to provide a paper addressing the following questions formulated by the Norwegian and Swedish Directorates of Education:

(1) What changes have been implemented, and why?

(2) How has the program helped to support you in the implementation of changes?

(3) What obstacles have you experienced in the effort to change practices?

(4) How did you overcome the obstacles?

(5) How does this develop on previous practices?

(6) Other comments or reflections

42 of the Norwegian participants and 20 of the Swedish participants in the program sent in reflection notes with rich descriptions of 4-10 pages. In this article, we draw on the reflection notes from the Norwegian participants, which include 23 
principals from primary school, 8 principals from secondary school, and 11 principals from upper secondary, together 19 women and 23 men. In sum, we received reflection notes from about $50 \%$ of the Norwegian participants from the three Benchlearning groups. Their length of service as a principal varied from a couple of years up to about ten years. The participants from Norway have completed the national school leadership development program and attended the Benchlearning program. Since the reflection notes should be anonymous and the number of participants was small, we did not ask them to provide personal information in the reflection papers. We have not taken gender into account.

In the presentation of empirical findings, we refer to the different reflection documents through coding: P1 (principal 1), P2, etc., given number after the participant list from 1-42, next, which group they had been part of (G1, G2, G3), and finally what school level they represented, primary (P), secondary (S) and upper secondary (US). The coding implies identifying which benchlearning group the principals have participated in and the school level, for example; principal 5, group 2, upper secondary (P5, G2, US). Methodologically, we have chosen a discursive approach to the analysis of documents. A discursive analysis aims to clarify how certain patterns in texts emerge from the main ideas embedded in the texts (Fairclough, 2003; Grønmo, 2004). In the first reading, each of the documents was analyzed in order to understand the whole (vertical). For the second reading, the documents were analyzed by comparing all answers to question 1 , to question 2, etc. (horizontal). We used content analysis to identify the two research topics a) changes in leadership and school practices and b) the program's contribution to the transformation of leadership and school practices. In the discussion, Kemmis'(2009) concepts understandings, doings, and relatings are used to illustrate how the transformations in leadership and school practices occur in the 
relation between what they do, what they think and say, and the ways they relate to others and to things and circumstances around them.

A methodological issue in action research is that the researchers have the dual role as both researchers and as process leaders for the program studied. In order to validate the study, the research team has been extended by an extern researcher bringing critical views and arguments from "outside" to the professional discussions. In addition, member checking has been used (Postholm, 2009). Findings from the study have been presented and discussed with the participants in a seminar in November 2017. One limitation is that we only have data from $50 \%$ of the participants. This could be a bias. The paper answers the questions regarding that particular selection of principals, who aimed to participate in the third meeting and writing the reflection notes. Due to the focus in this paper, we have not included possible issues regarding gender in our analysis.

\section{Results}

In the presentation of the results, we start with the participants" descriptions of changes in leadership and school practices and why these changes have been implemented, with reference to the first research topic. Next, the participants' ideas and reflections about how the program has supported the change process and their own learning are presented, with reference to the second research question. Excerpts from the participants' voices, with references to the principal number, group number and school level are used to exemplify and illustrate our findings. In addition, we present the numbers of participants reporting on the various change projects and topics for their reflections the contribution of the program. 


\section{Changes in Leadership and School Practices}

Three topics appear as change areas; innovative learning, the school's digital development and assessment for learning. The first two topics have been central in the Benchlearning program, while the assessment for learning reflects that many schools still work with one of the Directorate's initiatives. It is also interesting to see that several schools are working on developing collective professional practices among the staff and the leadership team. The group focus reflects the idea that development of new teaching practices must take place through the work of the professional learning communities (Aas, 2011; Filstad, 2017; Paulsen \& Aas, 2017). In the data, there is a clear link between more innovative learning and more collective practices. Sometimes the development process begins by discussing learning principles, while others start the process of establishing a collective knowledge and learning perspective in the staff. These different processes also illustrate that some of the participants use the Benchlearning program as a pretext for starting development work in their own school, while others connect to projects already in progress.

18 of the participants report that OECD's seven principles of innovative learning environments (ILE) have constituted a central focus area for change, either as an inspiration, as a "leading star" or as legitimation of own practice. All these participants point out that the focus on the ILE principles has helped to clarify for them that there is a need for more innovative teaching practices. Several participants report that working with the principles, both through the input of theory, school visits and reflection in the learning groups, has helped them as school leaders to "remain on the right track", exemplified by excerpts from one of the principals:

The implementation of the development project was influenced by the (OECD) ideas of innovative learning environments. We have emphasizes that in order to be 
innovative you need opportunities for trial and error. We will not make progress if we always have a fear of failure. (P15, G1, P)

Development work related to the school's digital development is mentioned by 19 participants. These are distributed among the three Benchlearning groups and the various school levels, with an overweight from group 3 that had the school's digital development as a special focus area. The change projects related to the use of digital technologies vary from projects that are on a planning stage to projects that have been in progress for a few years. There is obviously a significant variation between schools, and for some participants, the Benchlearning program represents a support to start with a digital change process, as one principal expresses it:

We are not a very advanced school with regard to digitization. This was one of the reasons why I applied to participate in the Benchlearning project. After our first meeting last year I decided to buy Google Chrome Books for students in 6th and 7th grade. (P17, G3, P)

A feedback from many participants (12 principals) is that they through participation in the program have become more convinced of the importance of establishing collective practices among teachers. This is achieved through organizational changes that increase the learning involvement, for example by establishing developmental groups at school, or by professional learning processes in the staff aimed at student learning. Several principals maintain that they have become more aware of the positive effects of their own participation, as principals, in these professional group processes. One principal expresses himself like this:

The work we do in our common time differs from what it used to be. Staff involvement is much broader now. Since they must contribute more with their own reflections when we construct a development project, I - as principal - feel that 
they develop a much stronger ownership to the process we're going through.(P11, $\mathrm{G} 2, \mathrm{P})$

The program focus on distributed leadership is reflected in several change process. 8 principals express that they are working on developing working modes that create distribution within the organization. They have initiated projects aimed at clarifying and changing roles in the leadership team with a new division of labour. Among these respondents, there seems to be broad consensus that distributed leadership is a prerequisite for creating innovative schools. Several of them reflect that more distributed leadership also requires that they themselves change their leadership style:

I came to the first meeting in Stockholm with many ideas and a lot of inspiration to change the way we run our school. What had motivated me the most, was to change my leadership style towards more distributed leadership. (P2, G1, P)

Many of the informants (13 principals) report that, through the Benchlearning program, they see the need for enhanced professional learning both in the school's leadership team and in the different teacher teams. This means that many of the change projects are linked to different forms of workplace learning grounded in sharing experiences and reflections among colleagues. Several principals indicate how significant sharing experiences and reflections have been for their own learning, as expressed by one of the principals:

To develop professional learning communities and establish relations with a view to enhance individual teacher knowledge relevant to the work we do, constitutes significant parts of the changes in our practice. (P14, G2, P)

\section{The Program's Contribution to Transformation of Leadership and School Practices}

On the question of how the program has helped to support the participants in implementing changes, the principals report that it is the overall methodology of the 
program, which has both inspired and supported them. The informants appreciate the thematic and theoretical focus of the program, the systematics of school visits, the establishment of learning groups, and the obligatory tasks between the seminars.

Participants emphasize the value of the inspiration they have received through the program's thematic and theoretical focus. The OECD's reports on "Innovative Learning" and "Leadership for 21 st Century Learning" were unknown to most of our informants before joining the program. Despite the fact that several of them found that the reports were demanding reading, participants' reflections show that reading and working with the documents in the seminars has been a strong source of inspiration for their own development efforts, both in terms of innovative learning (10 principals), distributed leadership (6 principals) and the school's digital development (5 principals):

When I think of my own school, this work differs most from earlier work with respect to staff involvement in the development process, and not to forget that the changes we have implemented are inspired by recent research and methods from other countries $(\mathrm{P} 2, \mathrm{G} 1, \mathrm{P})$

The methodology that was linked to the school visits was highly appreciated. The exhaustive preparations that were made in the learning groups before the school visits were highlighted. Together with the analysis the learning groups made after the visit, it created deeper reflections and a more systematic approach to observations than is usual for more unanticipated school visits. 15 participants explain how systematic work around the school visits actually created inspiration and motivation for change processes in their own context, exemplified by one of the principals:

Furthermore, I liked the concept and organization of the meetings, with texts to read in advance and work to do between modules. It was also interesting to participate in the preparations for the school visits, and the work we did after the 
visits. I think that these ways of working ensured better outcomes, and I have taken them to my own school. (P9, G2, P)

The permanent learning groups are emphasized as one of the program's success factors. Groups consisting of both Swedish and Norwegian principals seem to have contributed to the development of individuals in several ways. Being able to exchange experiences across schools and countries has contributed to a better understanding of how leadership at the same time is context-sensitive and has some common challenges. Many also find it gratifying to discuss leadership challenges with motivated and competent leaders from a different country. Despite the fact that the learning groups were only gathered physically on merely two occasions, secure and inclusive atmospheres for exchanges of experience and learning seem to have been established. An excerpt from one of the participants illustrates the impact on individual learning:

In a way I have been able to consider my development work a litle from the outside - through Benchlearning and input from others in my group. This has sort of given me a meta perspective where I have seen myself and my role from the outside through conversations and reflections with other head teachers in the program. (P19, G3, P)

The compulsory tasks between the seminars are also underscored as highly valuable. The fact that participants were required to implement new practices in their own schools and share the outcomes with other participants on Google Drive, instigated increased activity in schools. At the same time, many experienced that feedback from colleagues in their learning group supported a quality assurance of their own development projects. Listening to experiences from colleagues led to a more confident leadership practice and willingness to test new leadership and school practices, illustrated in the following excerpt: 
The leadership team felt that we came closer to and became more familiar with teaching in our institution, without having to spend a lot of time in individual classrooms ... I also feel very confident as a leader of this development work. One of the reasons for that is that I have both heard about it and seen it in practice and experienced that it is actually useful. (P5, G1, P)

Participants also explain how the modelling of the working modes of the Benchlearning program with theory input, the systematic approach to school visits and work in the learning groups seem to have contributed to actions in their own schools (17 principals). Some of the participants state that they have used the methodology in their own school, including school visits in their own municipality or schools in the neighbouring countries, as illustrated in the following excerpt:

Through Benchlearning I have been inspired to make many changes in my leadership and the way the school is run. Some of these changes have been inspired by lectures and the articles we have worked with in the meetings and read on my own, while a lot has been inspired by what we have experienced and observed during the school visits and what others have shared from their own practices. (P2, G1, P)

To sum up, the program has contributed to increase the participants a) inspiration and motivation for change (16 principals), b) confidence in the leadership role (10 principals), c) professional input and reflection (12 principals), d) reflectionbased and systematic approaches to change (8 principals), and e) new leadership practices, including a more closely approach to the teachers (11 principals).

In the following discussion, we consider the results in light of the literature on action research. Kemmis' (2009) concepts understandings, doings and relatings are used to illustrate how the transformations in leadership and school practices occur, and how the program has supported the change processes. 


\section{Discussion}

'Transformations in practice involve transformations in how people understand their practices, what they do, and how they relate to one another' (Kemmis, 2009, p. 467). Understandings, doings and relatings can each be transformed; however, each is always transformed in relation to the others. This means that transformation of the participants' leadership and school practices occur in the interaction between the principals' understandings, doings and relatings. In the following we discuss how the changes reported can be understood as transformations in understandings, doings and relatings, and the program's contribution to these transformations.

The findings show seven main areas of new practices. Innovative learning and the school's digital development reflect changes on classroom level. Collective practice and professional learning reflect changes on teacher level, while distributed leadership and learning leadership reflects changes on the leadership level. In the participants' reflections there seem to be connections between these change topics. The primary objective is to improve student learning. To do so, many of the principals consider it vital to first develop collective practices among the teachers, and if necessary enhance the teachers' professional learning about innovative learning or ICT. These changes may require a new and more distributed leadership structure and a new leadership style. New practices (doings) are grounded in a new cognitive frame of understanding student learning and school leadership. For many of the participants, this requires a shift from traditional managerial leadership to learning leadership, which is about setting direction and taking responsibility for making learning happen by creating innovative learning environments and communities of learning (MacBeath, 2013). Distributed leadership represents a cognitive shift in understanding leadership from a solo activity to a process involving interactions with others (Spillane, 2013). Transformations in doings (new 
practices) cannot be done without a new frame of understanding and ways of relating these new understandings to the participants' daily practice. Even though the main focus of change is innovative learning and the school's digital development, the variety of topics and levels for change among the participants demonstrate how they have their attention on relating new ideas to the school's tradition, culture and professional competence.

Investigations of how the program has contributed to transformations of the participants' leadership and school practices reveal four important learning modes. The informants appreciate the program's thematic and theoretical focus, the systematics of school visits, the established learning groups, and the obligatory tasks between the seminars. How has each of these learning modes supported the participants learning and transformations?

A thematic and theoretical focus has primarily helped the participants to maintain a shared focus in their learning process, and secondly, the theoretical knowledge has contributed to an enhanced understanding of the thematic area. New understandings seem to increase the participants' inspiration and motivation to try out new practices. This means that theory, that is general knowledge, can be an important starting point in transformations of new understandings and a prerequisite for new practices (doings).

The school visits represent an opportunity to see how theory can be transformed into school practice and in that way increase the participants' understandings. During the analytical process, entailing systematic individual and collective reflective activities (Carr \& Kemmis, 1986; Schön, 1991), the participants have to start a process of relating theory to real life. When the principals are asked to have a focal point for their observations and analyses, they are enabled to see how colleagues have related new 
ideas to circumstances in their schools. Observations of how other principals have transformed new ideas into daily practices have motivated them to try the same, however, with the necessary adaptations to their own contexts.

One of the learning modes the participants underscore as important is how the established learning groups have supported their learning, both as increased transformations in understandings and in relatings. Sharing experiences is an interactive process, including both telling and listening, and can only happen within an inclusive and safe environment (Aas, 2016b; Clutterbuck, 2007). Many of the participants find the group learning environment to be successful because on the one hand it is an arena for sharing and learning from experienced and enthusiastic colleagues and, on the other hand is an arena for learning, not "competition".

In action research doings seem to be at the heart of the learning process (Somekh \& Zeichner, 2009). The doings include testing new practices, reflecting on them and then using the reflections to create new knowledge and activities (Schön, 1987). The obligatory tasks between the seminars have given the participants new opportunities to learn. As the findings indicate, implementing new practices has both increased transformations in the participants' doings, relating and understandings. New actions represent new experiences and the possibility of new transformations of understandings and relatings. It does make a difference if the school leader thinks that he/she is part of the change process or if the change process is about others (Robertson, 2013). The practice (doings) is the focal point in a holistic learning mode (Huber, 2011). Interconnections among transformations in understandings, doings and relatings depend on reflective activities within each of them and on the interaction among them (Robertson, 2013). Since many principals consider metacognitive activities as something which normally comes in addition to their daily leadership practice, the 
process leaders in the Benchlearning program have had the role to promote individual and collective reflections to encourage double loop learning (Argyris \& Schön, 1978) and organizational learning (Hargrove, 2008). In doing so the process leaders have been both supportive and demanding, a combination the participants seem to appreciate:

Trough Benchlearning we get a professional update through literature studies. We get lectures and we are challenged by our outstanding process leaders in our group work. In addition to forming networks, nationally as well as to our neighbouring country, it is simply enormously exciting and provides valuable inputs contributing to development. (P11, G2, P)

\section{Conclusions and Implications}

In this paper, we have investigated how the Benchlearning program for principals in Norway and Sweden supports changes in Norwegian principals' school leadership practices. The program design builds on principles for action research. The findings show that the thematic and theoretical inputs of the program, practical training and learning modes stimulated transformations of the principals' thinking and talking about school and leadership practices, what they do in practice and how they relate to others and the circumstances around them. In particular, the study suggests that the principals' active participation in trialling new leadership practices in their own schools stimulated transformations.

The implications of the study can be summed up in following three principles: First, policymakers should take into account the fact that changing practices will be supplemented by changes in how the doings is thought about, talked about and justified. Shifts in sayings and doings will also involve shifts in the ways people relate to each other and to their context. Second, leadership programs should include trialling new practices as the focal learning mode, accompanied by individual and collective reflective activities. Third, educators should be trained as process leaders who can 
support transformations in leaders' understandings, doings and relatings in a demanding

and supportive way.

\section{References}

Aas, M. (2009). Diskusjonens kraft. En longitudinell studie av et skoleutviklingsprosjekt der leseeksperter/forskere støtter rektorer og loerere ved sju skoler i utvikling av skolens leseundervisning. (PhD. graden Monografi), Universitetet i Oslo, Oslo.

Aas, M. (2011). Ledelse av profesjonelle læringsfellesskap. In J. Møller \& E. Ottesen (Eds.), Rektor som leder og sjef: om styring, ledelse og kunnskapsutvikling $i$ skolen (pp. 186-201). Oslo: Universitetsforlaget.

Aas, M. (2016a). Bli en bedre skoleleder. Gruppecoaching som verktøy. Oslo: Universitetsforlaget.

Aas, M. (2016b). Leaders as learners: developing new leadership practices. Professional Development. doi:10.1080/19415257.2016.1194878

Aas, M., \& Blom, T. (2017). Benchlearning as Professional Development of School Leaders in Norway and Sweden Professional Development. doi:http://www.tandfonline.com/doi/full/10.1080/19415257.2017.1355840

Argyris, C., \& Schön, D. A. (1978). Organizational learning a theory of action perspective. Reading, Mass.: Addison-Wesley.

Carr, W., \& Kemmis, S. (1986). Becoming critical: education, knowledge, and action research. London: Falmer Press.

Clutterbuck, D. (2007). Coaching the Team at Work. London - Boston: Nicholas Brealey Publishing.

Cochran-Smith, M., \& Lytle, S. L. (1999). Relationship of Knowledge and Practice: Teacher Learning in Communities. In A. Iran-Nejad \& C. D. Pearson (Eds.), Review of Research in Education (Vol. 24, pp. 249-306). Washington DC: American Research Association.

Crow, G. M., \& Whiteman, R. S. (2016). Effective Preparation Program Features: A Literature Review. Journal of Research on Leadership Education, 11(1), 120148. doi:10.1177/1942775116634694

Darling-Hammond, L., LaPointe, M., Meyerson, D., \& Orr, M. (2007). Preparing school leaders for a changing world: Lessons from Exemplary Leadership Development Program. Retrieved from Stanford, CA: http://seli.stanford.edu

Dawson, T. L. (2008). Metacognition and learning in adulthood. A paper prepared in response to tasking from ODNI/CHCO/IC Leadership Development Office (Publication no. https://dts.lectica.org/PDF/Metacognition.pdf). Retrieved 15.10.2015

Dempster, N., Lovett, S., \& Fluckiger, B. (2011). Literature review: Strategies to develop school leadership. The Australian Institute for Teaching and School Leadership.

Fairclough, N. (2003). Analysing discourse. Textual analysis for social research. London and New York: Routledge.

Filstad, C. (2017). Ledelse for kompetanse - kompetent ledelse. In M. Aas \& J. M. Paulsen (Eds.), Ledelse i fremtidens skole (pp. 123-142). Oslo: Fagbokforlaget.

Fluckiger, B., Lovett, S., \& Dempster, N. (2014). Judging the quality of school leadership learning programmes: an international search. Professional Development in Education. doi:10.1080/19415257.2014.902861 
Fullan, M. (2015). The new meaning of educational change. New York: Teachers College Press.

Grønmo, S. (2004). Samfunnsvitenskapelig metode. Bergen: Fagbokforlaget.

Hallinger, P. (2011). Leadership for learning: lessons from 40 years of empirical research. Journal of Educational Administration, 49(2), 125-142.

Hallinger, P., \& Heck, R. H. (2010). Leadership for Learning: Does Collaborative Leadership Make a Difference in School Improvement? Educational Management Administration \& Leadership, 38(6), 654-678. doi: $10.1177 / 1741143210379060$

Hargreaves, A., \& Shirley, D. T. (2012). The Global Fourth Way: The Quest for Educational Excellence. Thousand Oaks: CA: Corwin.

Hargrove, R. A. (2008). Masterful coaching (3rd ed.). San Francisco: Jossey-Bass Pfeiffer.

Heck, R. H., \& Hallinger, P. (2014). Modeling the longitudinal effects of school leadership on teaching and learning. Journal of Educational Administration, 52(5), 653-681. doi:http://dx.doi.org/10.1108/JEA-08-2013-0097

Huber, S. G. (2010). New approaches in preparing school leaders. In P. Peterson, E. Baker, \& B. McGaw (Eds.), International encyclopedia of education (Vol. 4, pp. 752-761): Oxford: Elsevier.

Huber, S. G. (2011). Leadership for learning - Learning for leadership: The impact of professional development In T. Townsend \& J. MacBeath (Eds.), Springer International handbook of leadership for learning. Springer International Handbooks of Education 25. (pp. 635-652). Dordrecht: Springer.

Hunzicker, J. (2011). Effective professional development for teachers: a checklist. Professional Development in Education, 37(2), 177-179.

Jensen, R. (2017). School Leadership Development: What we know and how we know it. Acta Didactica Norway, 10(4), 46-68. doi:http://dx.doi.org/10.5617/adno.3898

Kemmis, S. (2009). Action research as a practice-based practice. Educational Action Research, 17(3), 463-474. doi:10.1080/09650790903093284

Kolb, D. A. (1984). Experiential learning experience as the source of learning and development. Englewood Cliffs, N.J.: Prentice-Hall.

Lovett, S., Dempster, N., \& Flückiger, B. (2015). Personal agency in ledership learning using an Australian heuristic. Professional Development in Education, 42(1), 127-143. doi:10.1080/19415257.2014.891532

Lucas, B., \& Claxton, G. (2010). New kinds of smart. How the science of learnable intelligence is changing education. London: Open University Press.

MacBeath, J. (2013). Leading learning in a world of change. In OECD (Ed.), Leadership for 21st Century Learning, Educational Research and Innovation (pp. 83-106): OECD Publishing.

McKinsey \& Company. (2010). Capturing the leadership premium: how the world's top school systems are building leadership capacity for the future (Publication no. http://mckinseyonsociety.com/downloads/reports/Education/schoolleadership_fi nal.pdf). (November 2010). Retrieved 09.02.2015

Møller, J. (2009). School leadership in an age of accountability: Tensions between managerial and professional accountability. Educational Change, 10, 37-46.

Møller, J., \& Skedsmo, G. (2013). Modernizing education - NPM reform in the Norwegian education system. Journal of Educational Administration and History, 45(4), 336-353. 
Nihlfors, E., \& Johansson, O. (2013). Rektor - en stark länk $i$ styrningen av skolan. Stockholm: SNS förlag.

OECD. (2008). Improving School Leadership: Policy and Practice. Paris: Organisation for Economic Cooperation and Development.

OECD. (2013a). Innovative Learning Environments. Paris: OECD Publishing.

OECD. (2013b). Leadership for 21st Century Learning, Educational Research and Innovation. In. Paris: OECD Publishing.

Paulsen, J. M., \& Aas, M. (2017). Fremtidens skoler ledes nå. In M. Aas \& J. M. Paulsen (Eds.), Ledelse i fremtidens skole (pp. 373-386). Oslo: Fagbokforlaget.

Postholm, M. B. (2009). Research and development work: developing teachers as researchers or just teachers? Educational Action Research, 17(4), 551-565.

Research, N. M. o. E. a. (2017). Loerelyst - tidlig innsats og kvalitet i skolen. Retrieved from https://www.regjeringen.no/no/dokumenter/meld.-st.-2120162017/id2544344/, April 15, 2018.

Robertson, J. (2013). Learning leadership. Leading and Managing, 19(2), 54-69.

Robertson, J. (2016). Coaching Leadership: Building Educational Leadership Capacity through Coaching Partnerships (Second ed.). Wellington: NZCER PRESS.

Robinson, V. M. J. (2010). From Instructional Leadership to Leadership Capabilities: Empirical Findings and Methodological Challenges. Leadership and Policy in Schools, 9(1), 1-26.

Schön, D. (1987). Educating the Reflective Practioner. Chicago: Jossey-Bass Publisher.

Schön, D. (1991). The reflective practitioner. How professionals think in action. New York: Basic Books, Inc. Publisher.

Skott, P., \& Kofod, K. K. (2013). Independent schools in different Nordic contexts: Implications for school leadership? In L. Moos (Ed.), Transnational Influences on Values and Practices in Nordic Educational Leadership: Is there a Nordic Model? (pp. 89-111). Doredrecht: Springer Science+Business Media B.V.

Somekh, B., \& Zeichner, K. (2009). Action research for educational reform: remodelling action research theories and practices in local contexts. Educational Action Research, 17(1), 5-21.

Spillane, J. P. (2013). The practice of leadning and managing teaching in educational organisations. In OECD (Ed.), Leadership for 21st Century Learning, Educational Research and Innovation (pp. 59-82): OECD Publishing.

Vennebo, K. F. (2015). School Leadership and Innovative Work Places and Spaces. (Doctoral Thesis), University of Oslo, Unipub forl, Oslo. 


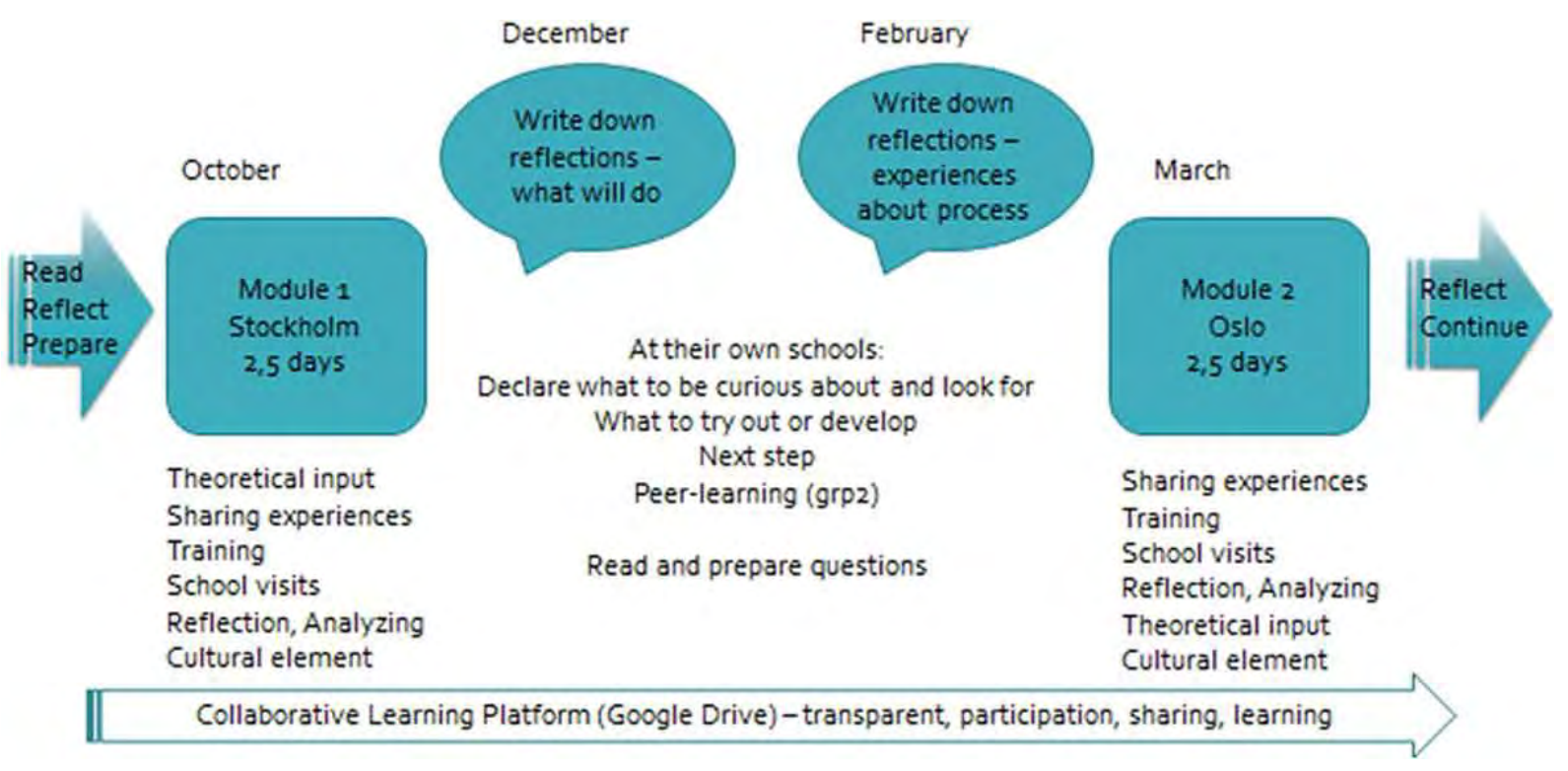

